УДК 004.42

Д. О. Карасьов, А. В. Максимюк, А. И . Савицькии

\title{
РОЗРОБКА МОДУЛЮ АВТОМАТИЗАЦІЇ ОФОРМЛЕННЯ ВІДПУСТОК НА БАЗІ МОДЕЛІ ПРОЦЕСІВ НАДАННЯ ВІДПУСТОК
}

Аннотація: У роботі представлені результати аналізу процесів надання відпусток працівникам вищого навчального закладу, розкрита декомпозиція функціонального забезпечення автоматизованної інформаційної системи, розроблений автоматизований модуль “Відпустки” для програмно-технологічного комплексу “ОК ВНЗ”.

Ключові слова: методологія SADT, бізнес-процес, відпустки, автоматизація, ПТК «ОК ВНЗ».

\section{Вступ}

Сучасною тенденцією в використанні засобів автоматизації процесів управління персоналом стає створення єдиної централізованої інформаційної системи управління персоналом, яка служить ефективним засобом для автоматизації роботи відділу кадрів. Єдина система дозволяє вводити дані однократно та, в подальшому, використовувати їх в різних видах кадрових операцій та обліку. В централізованій автоматизованій системі підтримується єдине інформаційне середовище, що надає можливість сформувати узагальнені звіти та отримати необхідну інформацію для керівництва університету.

В сучасному навчальному закладі кадрове діловодство є важливим елементом в управлінні персоналом. При цьому ведення обліку кадрів являє собою трудомісткий i тривалий процес, при якому необхідно постійно враховувати особливості Кодексу законів про працю України [1] та Трудового законодавства, пов' язаних з кадровим обліком, і постійно відслідковувати законодавчі зміни.

Також слід враховувати, що відділ кадрів повинен, відповідно до законодавства України, організувати ефективну систему захисту персональних даних працівників [2]. Мається на увазі, що навчальний заклад не може збирати про співробітників деякі види інформації (про віросповідання, політичні погляди і т.п.), дані про працівників повинні бути суворо конфіденційними (як на організаційному, так і технічному рівні). Також навчальний заклад не може використовувати програмно-

\footnotetext{
${ }^{\circledR}$ Д. О. Карасьов, А. В. Максимюк, А. И. Савицькии
} 
технічні засоби стеження за персоналом, підслуховування їх телефонних розмов без їх відома, порушувати таємницю листування, в т.ч. в електронній формі, і здійснювати інший збір інформації про персонал.

В Україні перевірку правильності ведення кадрового діловодства та дотримання трудового законодавства здійснює ряд наглядових органів - центр зайнятості, фонди соціального страхування, інспекції 3 охорони праці. Основний контроль здійснює Департамент нагляду за додержанням законодавства про працю Міністерства праці України. Не дотримання різних аспектів законодавства про працю призводить до матеріальної, адміністративної та кримінальної відповідальності.

Для автоматизації обліку персоналу в КПІ ім. Ігоря Сікорського працівниками КБ інформаційних систем розроблена перша черга програмно-технологічного комплексу «Облік кадрів вищого навчального закладу» (ПТК «ОК ВНЗ»). Це е розподілена клієнт-серверна інформаційна система, що забезпечує автоматизовану підготовку, пошук i обробку інформації в рамках інтегрованих мережевих, комп'ютерних і комунікаційних технологіях, i вирішує задачу підвищення ефективності діяльності в адміністративно-кадровій сфері управління. Робота ПТК «ОК ВНЗ» призвела до зменшення кількості помилок інспекторами відділу кадрів університету [3].

ПТК «ОК ВНЗ» складається з підсистем:

- «Особова справа» - призначена для створення сукупності електронних документів, які містять найповніші відомості про працівника i характеризують його біографічні, ділові, особисті якості; вона займає основне місце у системі персонального електронного обліку працівників.

- «Звіти» - призначена для видачі в електронному вигляді регламентованих параметризованих звітів та звітів за заданими параметрами опису працівника ВНЗ з можливістю побудови відповідних діаграм.

- «Пошукова система» - призначена для пошуку та аналізу інформації за заданими параметрами, обробки знайденої інформації, формування та друку знайденої інформації.

- «Статистика» - призначена для проведення статистичного аналізу щодо заповнення бази персональних даних «Працівники» за критеріями: створення нової особової справи, редагування особової справи (за полями). 
Підсистема «Особова справа» (рис. 1) має розподіл на окремі програмно-технологічні складові [4][5]:

- особиста інформація;

- заохочення;

- стягнення;

- посвідчення;

- призначення та переміщення;

- пенсійне забезпечення.

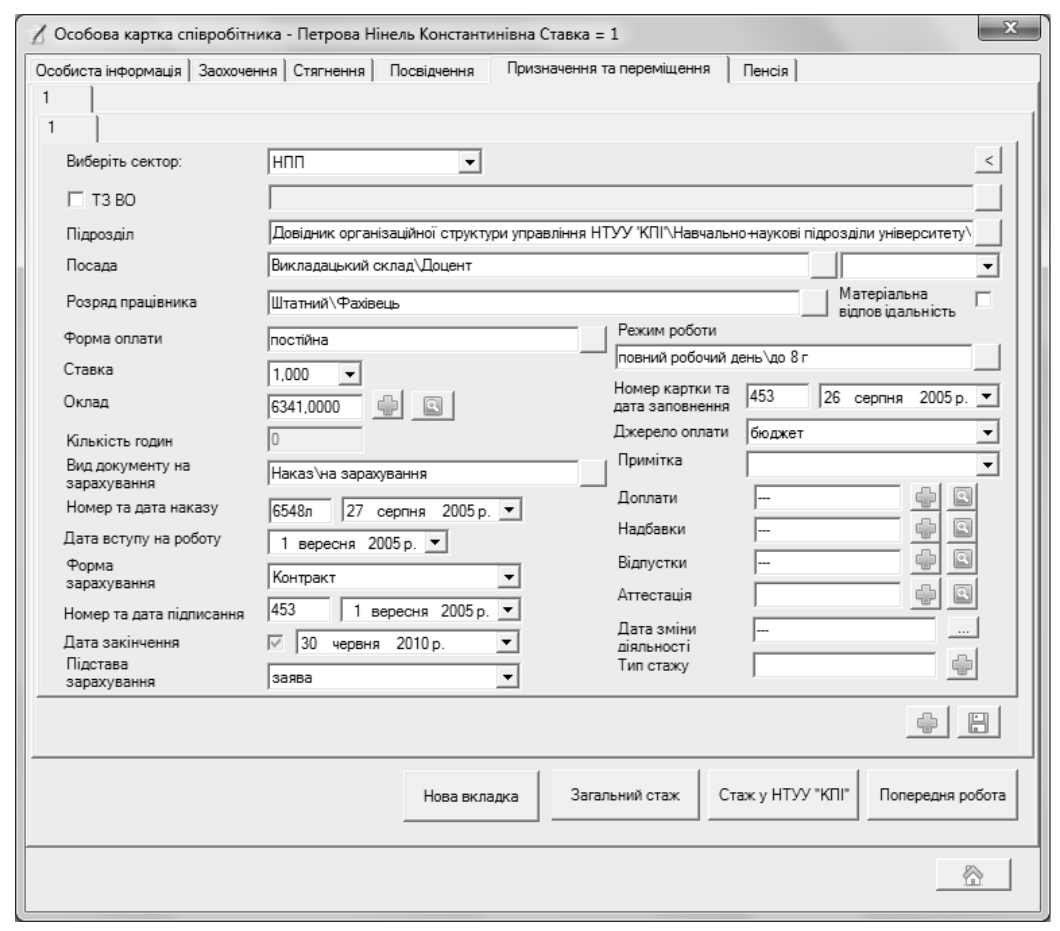

Рис. 1. Особова справа працівника

В КПІ ім. Ігоря Сікорського, при загальній кількості більше семи тисяч працівників, відділ кадрів, окрім обліку особового складу, веде додатково облік і по інших напрямках роботи з особовим складом, наприклад, облік відпусток.

Важливість та необхідність обліку відпусток підкреслює наявність в державі спеціального Закону України (ЗУ) «Про відпустки» від 15.11.96 p. № 504/96-BР.

Головна умова для визначення права на відпустку — перебування у трудових відносинах, закріплених у трудовому договорі.

Згідно ч. 3 ст. 2 ЗУ «Про відпустки» [6] право на відпустки забезпечується гарантованим наданням відпустки визначеної тривалості із збереженням, на їі період, місця роботи (посади), заробітної плати (допомоги) у випадках, передбачених законом. 
Також відповідно до ст.11 ЗУ «Про відпустки» забороняється ненадання щорічних відпусток повної тривалості протягом двох років підряд, а також ненадання їх протягом робочого року особам віком до вісімнадцяти років та працівникам, які мають право на щорічні додаткові відпустки за роботу із шкідливими і важкими умовами чи з особливим характером праці.

За порушення законодавства України про працю, у частині ненадання відпустки, роботодавець несе відповідальність згідно з чиннил законодавствол [7].

Відпустка являє собою дуже важливу складову робочого процесу навчального закладу.

\section{Постановка задачі}

Провести аналіз та проектування бізнес - процесів для автоматизації процесу надання й врахування відпусток за допомогою методології SADT.

Розробити автоматизований модуль оформлення відпусток з використанням моделей бізнес - процесів, які будуть розробленні, наступними складовими:

- Бізнес процес “Оформлення нової відпустки”;

- Бізнес процес “Подовження відпустки”;

- Бізнес процес “Відклик з відпустки”;

- Бізнес процес “Компенсація відпустки”;

- Бізнес процес “Редагування існуючих відпусток”;

- Бізнес процес “Відпустки минулих років”.

\section{Вирішення задачі}

Сутність структурного підходу до розробки автоматизованої інформаційної системи полягає в її декомпозиції: функціональне забезпечення представляється у вигляді функціональних підсистем, які, в свою чергу, поділяються на модулі, компоненти та інше. Процес розбиття продовжується до зазначення конкретних процедур. При цьому система зберігає цілісність взаємопов'язаних складових.

\section{Функціональне проектування модуля «Відпустки»}

Для вирішення поставлених задач був проведений аналіз процесів документообігу відділу кадрів університету, де була виявлена можливість раціоналізації його за рахунок зменшення дублюючої інформації. 
В результаті проведеного аналізу предметної області була розроблена функціональна модель бази даних для модуля «Відпустки». Проектування бізнес-процесів відбувалося за допомогою методології SADT.

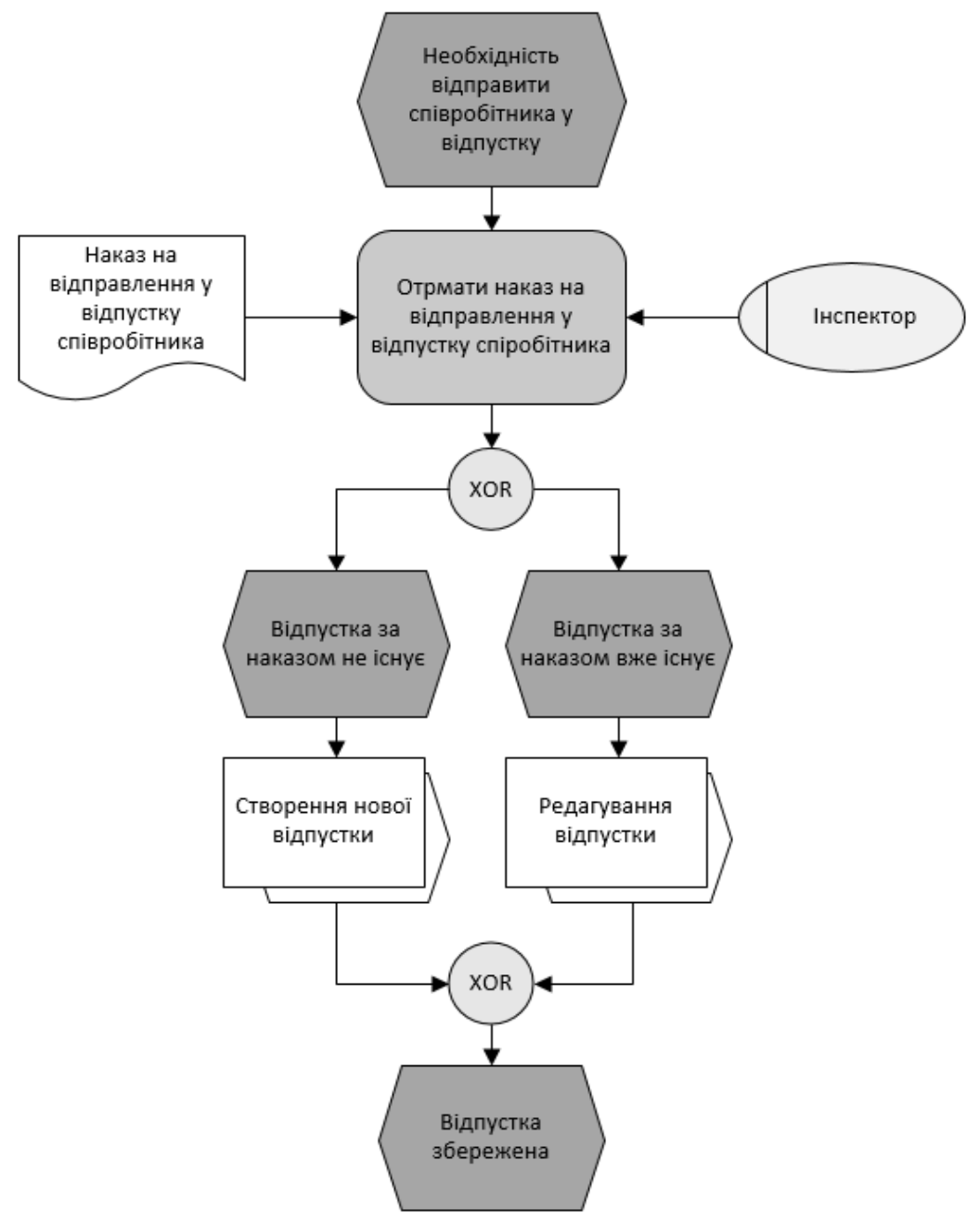

Рис. 2. Схема деталізації бізнес-процесу

Функціональна декомпозиція модуля «Відпустки» представлена на рис. 3.

Декомпозиція модуля «Відпустки» дала можливість визначити для реалізації наступні функції:

- Вихід працівника за видом у відпустку;

- Подовження працівником відпустки за видом;

- Відклик працівника з щорічної відпустки;

- Компенсація працівникові щорічної відпустки;

- Переривання щорічної відпусти через лікарняний.

Розглянемо більш детально взаємодію роботи складових модуля «Відпустки» [8]. 


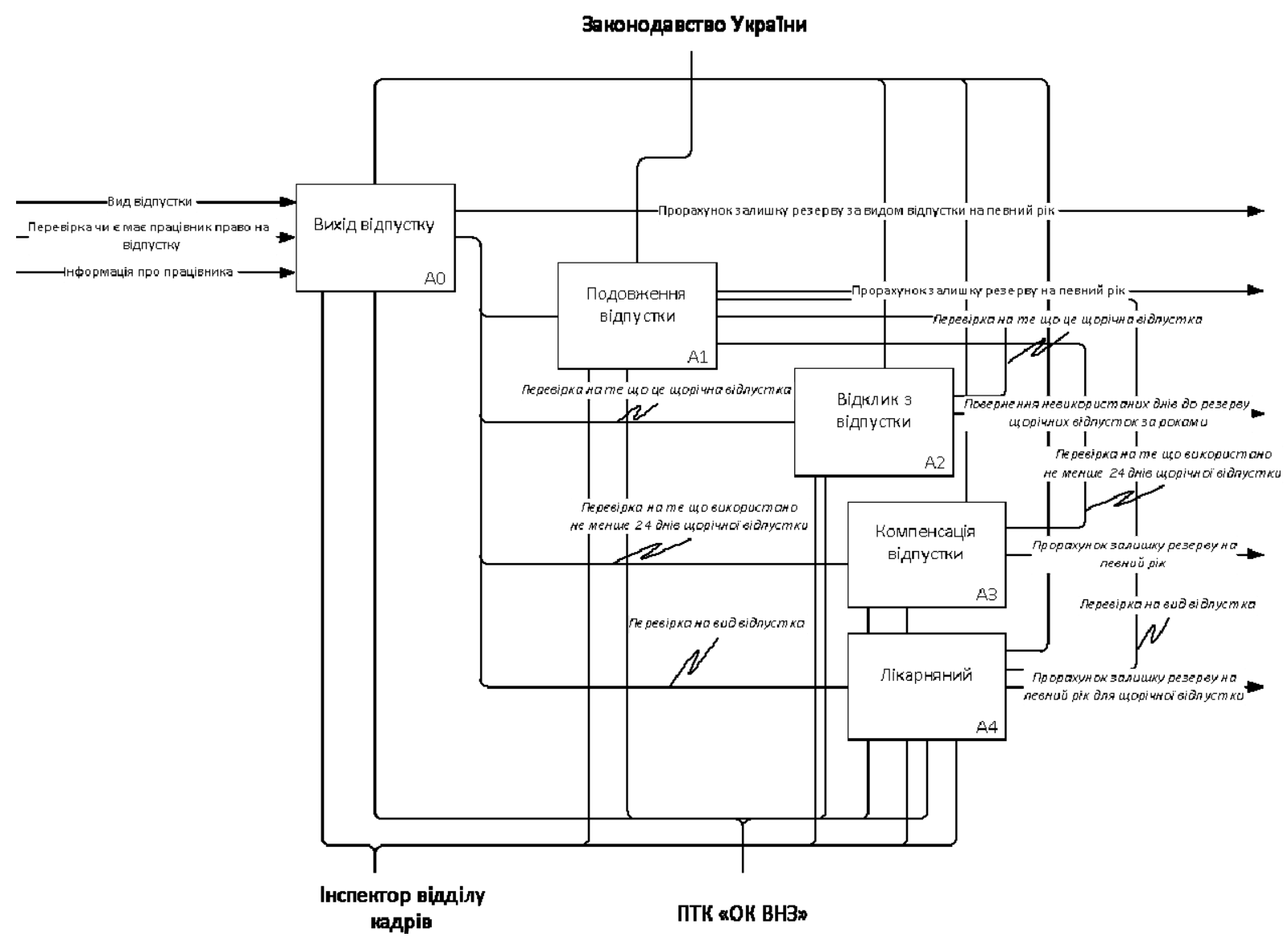

Рис. 3. Функціональна декомпозиція модуля «Відпустки»

Робота інспектора відділу кадрів з модулем починається з форми “Історія відпусток” (рис.4), у якій представляється інформація про використані відпустки працівника та залишок резерву. За бажанням інспектора відпустки будуть впорядковуватися або за типом відпустки, чи за роком.

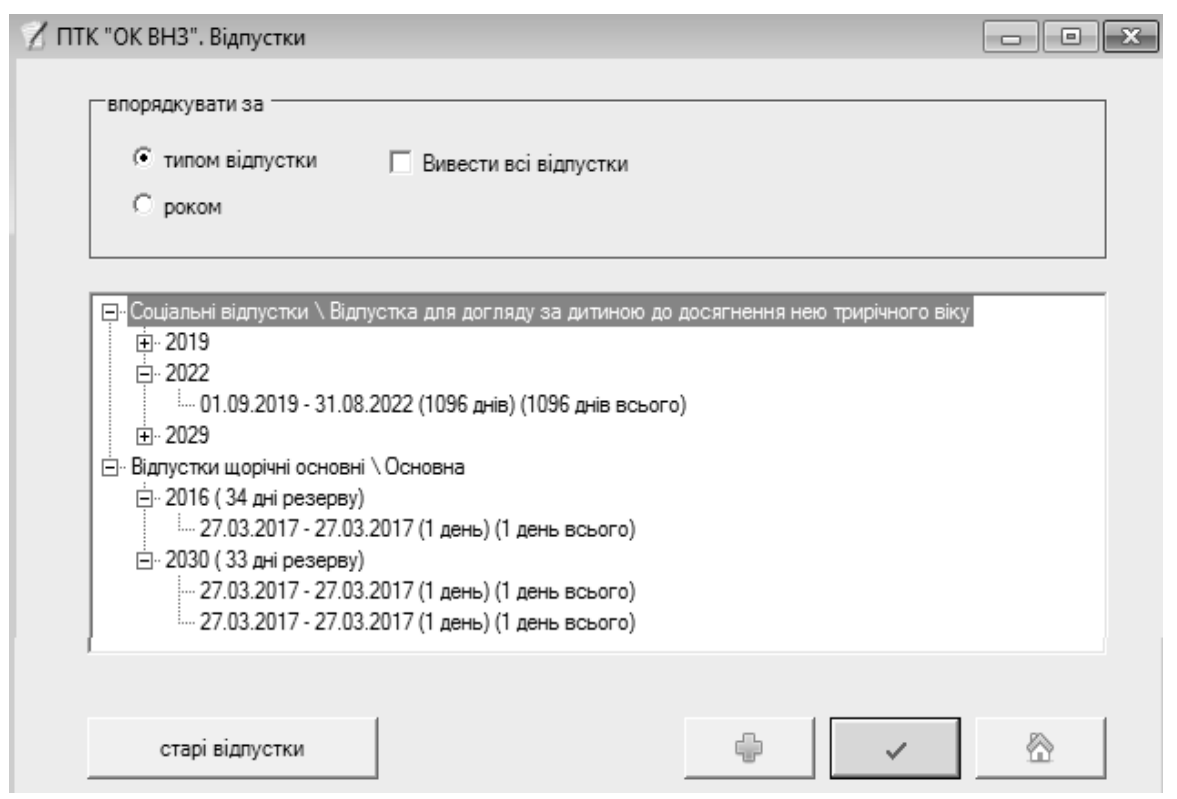

Рис. 4. Історія відпусток 
За структурою модуль «Відпустки» складається з наступних частин:

- Нова відпустка;

- Редагування;

- Відпустки минулих років.

В першу чергу інспектор має можливість отримати вичерпну інформацію про відпустки працівника, коли він працював на певній роботі по роках зі зазначенням залишку резерву щорічних та соціальних відпусток.

Функціональна декомпозиція активності «Щорічної відпустки» представлена на рис. 5 .

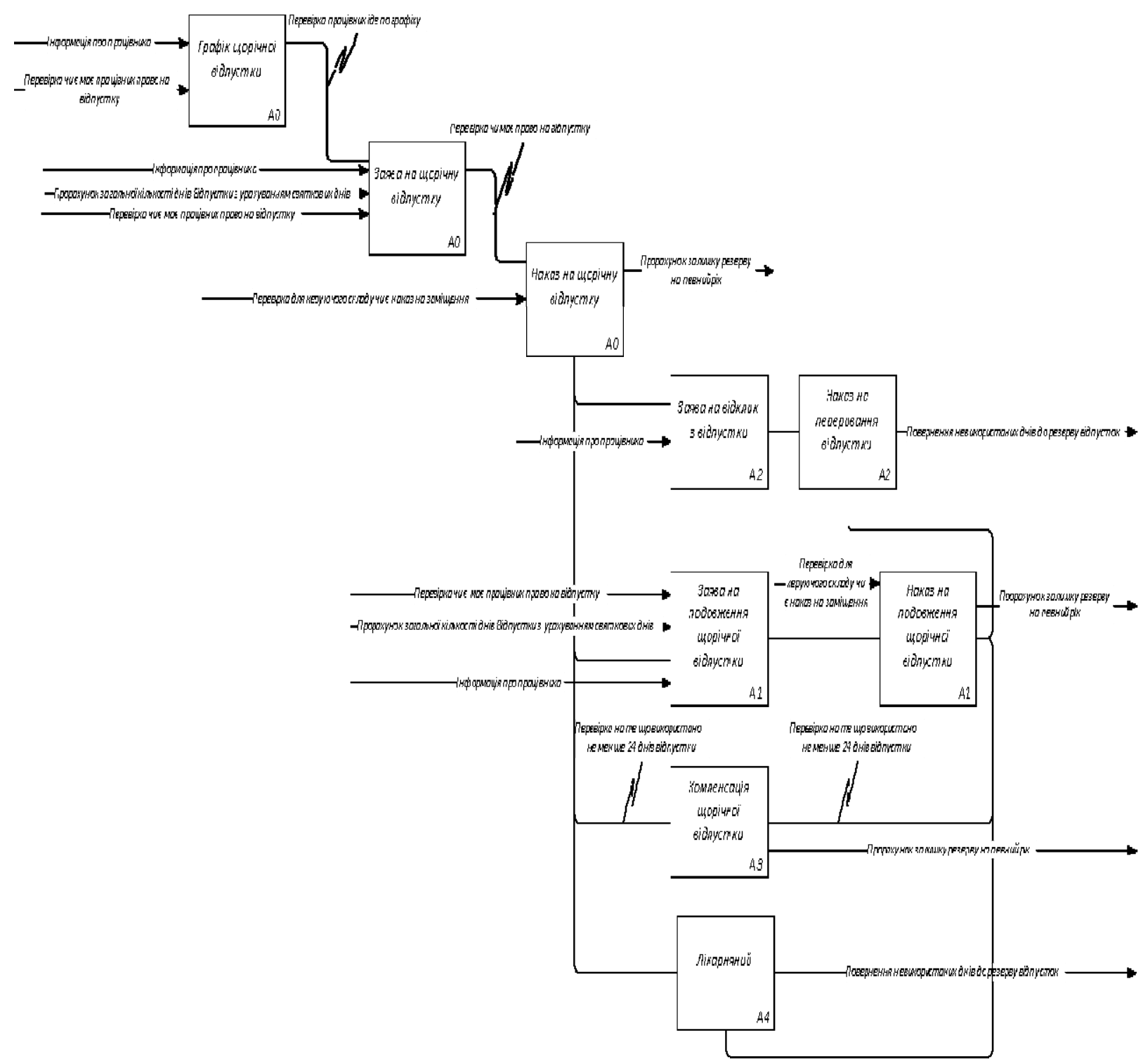

Рис. 5. Функціональна декомпозиція активності «Щорічної відпустки» 
При необхідності створення нової відпустку (отримання наказу про надання відпустки) відбувається перехід на форму «Створення нової відпустки» (рис.6).

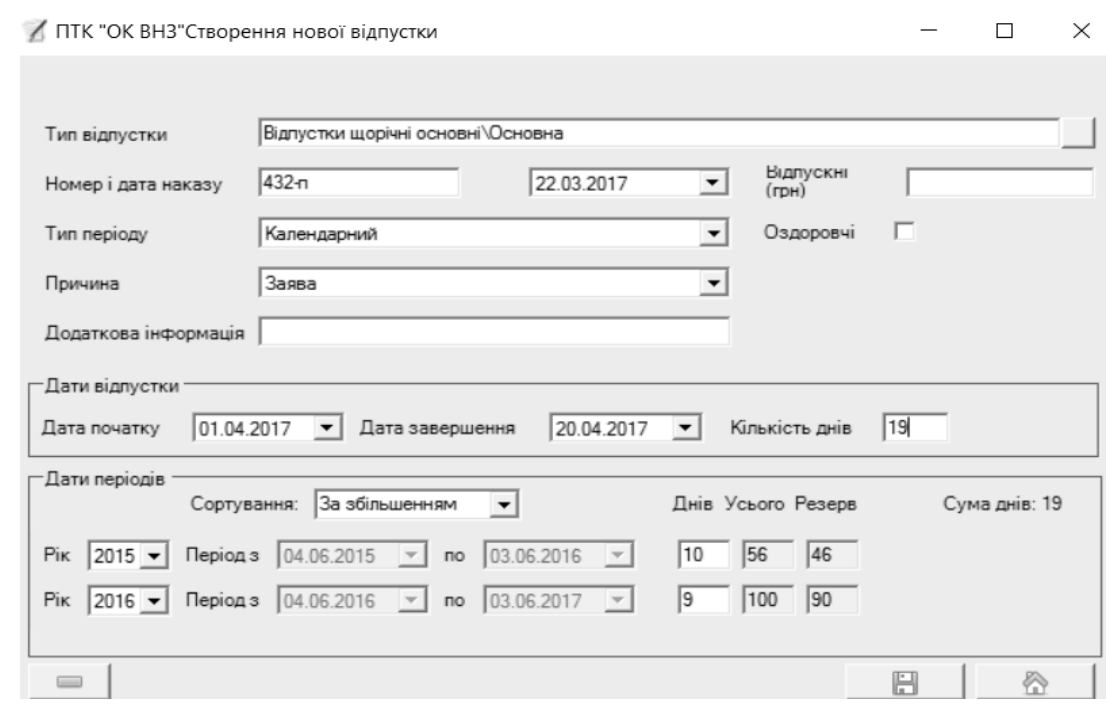

Рис. 6. Створення нової відпустки

В цій формі інспектор вносить інформацію:

- тип відпустки (щорічна основна, додаткові відпустки: у зв'язку з навчанням, творча, соціальна, без збереження, чорнобильська, для окремих категорій ветеранів війни);

- реквізити наказу;

- період відпустки (календарний, учбовий);

- дата відпустки.

В залежності від полів «Тип відпустки», «Дата початку» та «Дата завершення» кількість днів відпустки розраховується автоматично. Згідно чинного законодавства при визначенні тривалості щорічної відпустки не враховуються святкові та неробочі дні.

В групі «Дата періодів» відображаються:

- рік, в якому у працівника за видом відпустки залишився резерв.

- період роботи - рік вираховується автоматично з дати початку роботи; але, якщо працівник знаходився у відпустці за доглядом за дитиною, цей час у прорахунок періоду роботи не враховується.

Загальну кількість днів, яку працівник бере на час відпустки, можна розбити за декількома періодами роботи.

Резерв прораховується автоматично, де враховуються усі надані, подовжені, відкликані або компенсовані відпустки працівнику за певний рік роботи за типом відпустки. 


\section{Висновки}

В даній статті був проведений аналіз задачі оформлення відпусток, на базі якого були спроектовані моделі бізнес-процесів надання відпусток за допомогою методології SADT. Для вирішення поставлених задач згідно чинного законодавства був розроблений автоматизований модуль “Відпустки” для ПТК “ОК ВНЗ”, який дає можливість інспектору відділу кадрів контролювати інформацію про:

- резерв відпустки (по роках) відповідно їі типу для кожного працівника;

- наявності в базі даних ПТК «ОК ВНЗ», працівників, які не були у відпустці більше 2 років;

- отримання компенсації за невикористані дні відпусток при звільненні працівника;

- можливості надання працівнику подовження відпустки;

- відклику працівника з щорічної відпустки;

- надання працівнику певних видів відпустки тільки при наявності лікарняного;

- надання працівнику компенсації невикористаних днів щорічної відпустки.

\section{Список використаних джерел}

1. Кодекс законів про працю України від 10.12.71 р.:- Режим доступа :- http://zakon2.rada.gov.ua/laws/show/322-08

2. Закон України «Про захист персональних даних» від 01.06.2010 № 2297-VI. :- Режим доступа :- http://zakon0.rada.gov.ua/laws/ /show/2297-17

3. Інноваційні комп'ютерні технології у вищій школі : матеріали 2-ої Науково-практичної конференції, 23-25 листопада 2010 року, Львів / Національний університет “Львівська політехніка". - Львів: Видавництво Національного університету “Львівська політехніка” // Савицький А. Програмно-технологічний комплекс «Облік кадрів ВНЗ» / А. Савицький, О. Габзовська, А. Максимюк - 2010. - С. 101-103.

4. Сборник научных трудов SWorld. Материалы международной научно- практической конференции «Современные направления теоретических и прикладных исследований '2012». // Максимюк А. В., Рибак С. М., Савицький А. Й. Аналіз та структурізація особової справи співробітника ВНЗ в єдиному інформаційному середовищі університету - 
Выпуск 1. Том 5. - Одесса: КУПРИЕНКО, 2012. - ЦИТ: 112-858 C. $39-41$.

5. Сборник научных трудов SWorld. Материалы международной научно- практической конференции «Современные направления теоретических и прикладных исследований '2014». // Максимюк А. В., Найденко Є. І., Савицький А. Й. Особливості організації роботи програмно-технологічного модуля «Нова особова справа працівника» в програмно-технологічному комплексі «Облік кадрів вищого навчального закладу» - $2014-$ C.36-42.

6. Закон про відпустки - Закон України «Про відпустки» від 15.11.96 p. № 504/96-BР.:- Режим доступа : - http://zakon0.rada.gov.ua/ /laws/show/504/96- \% D0\% B2\% D1\% 80

7. Кодекс України про адміністративні правопорушення від 07.12.1984 № 8073-X.

8. Сборник научных трудов SWorld. Материалы международной научно- практической конференции «Современные направления теоретических и прикладных исследований '2012». // Александров С. С., Максимюк А. В., Савицький А. Й. Аналіз моделі динамічного пошуку в автоматизованій інформаційній системі «Облік кадрів ВНЗ»- Выпуск 1. Том 5. - Одесса: КУПРИЕНКО, 2012. - ЦИТ: 112-860 - С.39-41. 